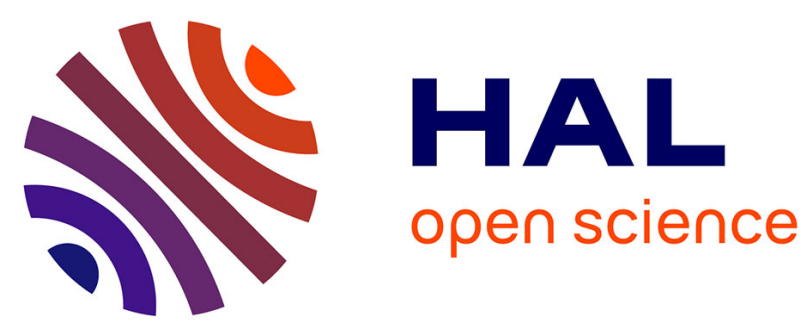

\title{
Colossal Magnetoresistance in La1-xPbxMnO3 Thin Films Prepared by Pulsed Laser Deposition
}

\author{
B. Holzapfel, A. Hütten, D. Eckert, K.-H. Müller, L. Schultz
}

\section{To cite this version:}

B. Holzapfel, A. Hütten, D. Eckert, K.-H. Müller, L. Schultz. Colossal Magnetoresistance in La1xPbxMnO3 Thin Films Prepared by Pulsed Laser Deposition. Journal de Physique IV Proceedings, 1997, 07 (C1), pp.C1-637-C1-638. 10.1051/jp4:19971263 . jpa-00254973

\section{HAL Id: jpa-00254973 https://hal.science/jpa-00254973}

Submitted on 1 Jan 1997

HAL is a multi-disciplinary open access archive for the deposit and dissemination of scientific research documents, whether they are published or not. The documents may come from teaching and research institutions in France or abroad, or from public or private research centers.
L'archive ouverte pluridisciplinaire HAL, est destinée au dépôt et à la diffusion de documents scientifiques de niveau recherche, publiés ou non, émanant des établissements d'enseignement et de recherche français ou étrangers, des laboratoires publics ou privés. 


\title{
Colossal Magnetoresistance in $\mathrm{La}_{1-x} \mathrm{~Pb}_{x} \mathrm{MnO}_{3}$ Thin Films Prepared by Pulsed Laser Deposition
}

\author{
B. Holzapfel, A. Hütten, D. Eckert, K.-H. Müller and L. Schultz \\ IFW Dresden, P.O. Box 270016, 01171 Dresden, Germany
}

\begin{abstract}
La}_{1-\mathrm{x}} \mathrm{Pb}_{\mathrm{x}} \mathrm{MnO}_{3}$ thin films were prepared by off-axis pulsed laser deposition from stoichiometric targets on $\mathrm{SrTiO}_{3}$ and $\mathrm{LaAlO}_{3}$ substrates using $\mathrm{KrF}$ excimer laser radiation $(248 \mathrm{~nm})$. Thin film deposition was performed at substrate temperatures between $650^{\circ} \mathrm{C}$ and $850^{\circ} \mathrm{C}$ and an oxygen pressure of $0.4 \mathrm{mbar}$. Thin films prepared at $750^{\circ} \mathrm{C}$ were single phase and (001)-oriented. Epitaxial film growth was confirmed by $x$-ray pole figures and RHEED. Magnetic properties were studied by SQUID magnetometry. Ferromagnetic behavior with Curie temperatures between $200^{\circ} \mathrm{C}$ and $300^{\circ} \mathrm{C}$ was observed to be dependent on deposition parameters. Magnetoresistance was examined by standard 4-point measurements in fields up to $8 \mathrm{~T}$. As an example, a film with $T_{c}=193 \mathrm{~K}$ shows a resistance change $((\rho(0)-\rho(H)) / \rho(0))$ of about $25 \%$ at $T=300 \mathrm{~K}$. For $\mathrm{T}=220 \mathrm{~K}$ and $180 \mathrm{~K}$ the changes are $70 \%$.
\end{abstract}

\section{INTRODUCTION}

In the past years the giant magnetoresistance (GMR) behavior in metallic multilayers received much attention due to possible industrial applications in magnetic sensors. Recently, large GMR effects called colossal magnetoresistance (CMR) effects were reported for perovskite oxides such as $\mathrm{La}_{\mathbf{x}} \mathrm{A}_{\mathrm{l}-\mathrm{x}} \mathrm{MnO}_{3}(\mathrm{~A}: \mathrm{Sr}, \mathrm{Ca}, \mathrm{Ba}$, etc.). The CMR ratios $((\rho(0)-\rho(H)) / \rho(H))$ so far reported ranged up to $1 \times 10^{5} \%$ at $77 \mathrm{~K}$ for $\mathrm{La}-\mathrm{Ca}-\mathrm{Mn}-\mathrm{O}$ films [1] and $5 \times 10^{5} \%$ at $88 \mathrm{~K}$ for Pr-Sr-Ca-Mn-O [2]. At or close to room temperature, which is the necessary operating temperature for technical applications, the CMR effects are much smaller : $150 \%$ at $300 \mathrm{~K}$ and $7 \mathrm{~T}$ for $\mathrm{La}-\mathrm{Ba}-\mathrm{Mn}-\mathrm{O}$ thin films [3] or $400 \%$ in an annealed $\mathrm{La}-\mathrm{Ca}-\mathrm{Mn}-\mathrm{O}$ film at $280 \mathrm{~K}$ and $6 \mathrm{~T}$. Another interesting system which shows high CMR ratios in bulk samples of up to $560 \%$ at $320 \mathrm{~K}$ and $6 \mathrm{~T}$ is $\mathrm{La}-\mathrm{Pb}-\mathrm{Mn}-\mathrm{O}$ [4-6]. In this work we report on the preparation of $\mathrm{La}-\mathrm{Pb}-\mathrm{Mn}-\mathrm{O}$ thin films and their characterization.

\section{EXPERIMENTAL}

Bulk targets of $\mathrm{La}_{\mathrm{x}} \mathrm{Pb}_{1-\mathrm{x}} \mathrm{MnO}_{3}$, where $\mathrm{x}=0.2$, were prepared from a stoichiometric mixture of $\mathrm{PbO}_{2}, \mathrm{La}_{2} \mathrm{O}_{3}$ and $\mathrm{MnCO}_{3}$ by standard calzination $\left(800^{\circ} \mathrm{C}, 24 \mathrm{~h}\right)$ and sintering $\left(1200^{\circ} \mathrm{C}, 24 \mathrm{~h}\right)$ procedures. The resulting targets were single phase with a density of $74 \%$ of the theoretical density. A KrF $(248 \mathrm{~nm})$ excimer laser was used to deposit the films on (100) SrTiO $_{3}$ (STO) and $\mathrm{LaAlO}_{3}$ substrates using an energy density of $2 \mathrm{~J} / \mathrm{cm}^{2}$ at the target. The deposition was carried out in a pure $\mathrm{O}_{2}$ athmosphere of $0.4 \mathrm{mbar}$ using the off-axis deposition geometry [7]. The substrate temperature during thin film deposition ranged between $650^{\circ} \mathrm{C}$ and $850^{\circ} \mathrm{C}$ for a substrate to target distance of $6 \mathrm{~cm}$. After the deposition process the films cooled down to room temperature in $400 \mathrm{mbar} \mathrm{O}_{2}$. The typical film thickness was about $200 \mathrm{~nm}$. X-ray diffraction and RHEED have been used for the structural characterization of the films. Magnetization measurements were performed using a commercial SQUID magnetometer. The magnetoresistance measurements were made using a conventional four-point technique in a temperature range of $4 \mathrm{~K}$ to $300 \mathrm{~K}$ and magnetic fields up to $8 \mathrm{~T}$. The CMR ratio is defined as $\rho(H)-\rho(0) / \rho(0)$.

\section{RESULTS AND DISCUSSION}

X-ray diffraction indicate that the deposited films have the perovskite-type cubic structure with a lattice parameter of $\mathrm{a}=3.895 \AA$. They were single phase with a strong $(001)$ orientation. Epitaxial film growth on $\mathrm{LaAlO}_{3}$ was proven by X-ray pole figures and RHEED. 
Figure 1 gives the temperature dependence of the magnetization of a thin film deposited at a substrate temperature of $750^{\circ} \mathrm{C}$, measured in an applied field of $0.1 \mathrm{~T}$. The Curie point $\mathrm{T}_{\mathrm{c}}=193 \mathrm{~K}$ is defined as the point where $\mathrm{dM} / \mathrm{dT}$ reaches the maximum value. $A$ linear extrapolation of the high temperature susceptibility $1 / \chi$ gives the paramagnetic Curie point $\Theta_{p}=205 \mathrm{~K}$. The reduction of $\mathrm{T}_{\mathrm{c}}$ compared to bulk samples $\left(T_{c}=320 \mathrm{~K}[4]\right)$ is possibly due to film oxygen deficiency which changes the doping level and therefore the mixed $\mathrm{Mn}^{3+} / \mathrm{Mn}^{4+}$ ratio determining the ferromagnetic behavior, as stated for $\mathrm{La}-\mathrm{Ba}-\mathrm{Mn}-\mathrm{O}$ thin films [8]. This oxygen deficiency is partly caused by the off-axis deposition geometry, as it was shown for YBaCuO thin films [7]. The Curie point of films deposited at different temperatures shows a maximum of $\mathrm{T}_{\mathrm{c}}=198 \mathrm{~K}$ at a substrate temperature of $700^{\circ} \mathrm{C}$. The reduced $\mathrm{T}_{\mathrm{c}}$ at high substrate temperatures $\left(>800^{\circ} \mathrm{C}\right)$ is possibly due to loss of $\mathrm{Pb}$ during the thin film deposition process.

Figure 2 shows the magnetoresistance effect at temperatures around the Curie temperature and at room temperature with the current parallel to the magnetic field. The CMR ratios at $8 \mathrm{~T}$ are about $25 \%$ at room temperature and increased to $70 \%$ at $180 \mathrm{~K} / 220 \mathrm{~K}$. The change in the curvature of the magnetoresistance below and above the Curie temperature is similar to that observed in La-Pb-Ca-Mn-O single crystals [9]. Therefore the low-field magnetoresistance effect is extremely different below and above the Curie temperature. At $0.1 \mathrm{~T}$ and $20 \mathrm{~K}$ below $\mathrm{T}_{\mathrm{c}}$ the magnetoresistance ratio is $3 \%$, but only $0.12 \% 20 \mathrm{~K}$ above Tc. This behavior shows, that it is more useful for potential applications to increase the Curie temperature of the thin films to room temperature than optimizing the high field CMR ratio at low temperatures.

In summary, epitaxial $\mathrm{La}-\mathrm{Pb}-\mathrm{Mn}-\mathrm{O}$ thin films were prepared by off-axis pulsed laser deposition on $\mathrm{SrTiO}_{3}$ and $\mathrm{LaAlO}_{3}$ substrates. The films showed reduced Curie temperatures compared to bulk samples of the same composition due to oxygen deficiency. The magnetoresistance ratio near the Curie temperature shows values up to $70 \%$ at $8 \mathrm{~T}$. At room temperature the films show a magnetoresistance ratio of about $25 \%$.

\section{Acknowledgments}

The authors gratefully acknowledge technical assistance from U. Fiedler and S. Friedrichs.

\section{References}

[1] S. Jin, T.H. Tiefel, M. McCormack, H.M. O Bryan, L.H. Chen, R. Ramesh, and D. Schurig,

[2] B. Raveau, A. Maignan, and V. Caignaert, J. of Solid State Chem. 117, 424 (1995) Appl. Phys. Lett. 67, 557 (1995)

[3] R. von Helmolt, J. Wecker, B. Holzapfel, L. Schultz, and K. Samwer, Phys. Rev. Lett., 71, 2331 (1993)

[4] R. Mahendiran, R. Mahesh, A. K. Raychaudhuri, and C.N.R. Rao, J. Phys. D : Appl. Phys. 28, 1743 (1995)

[5] K.M. Satyalakshmi, S.S. Manoharan, M.S. Hedge, V. Prasad, and S.V. Subramanyam, J. of Appl. Phys. 78, 6861 (1995)

[6] C.W. Searle and S.T. Wang, Canadian J. of Physics, 48, 2023 (1970)

[7] B. Holzapfel, B. Roas, L. Schultz, P. Bauer, and G. Saemann-Ischenko, Appl. Phys. Lett. 61, 3178 (1992)

[8] G.C. Xiong, Q. Li, H.L. Ju, R.L. Greene, and T. Venkatesan, Appl. Phys. Lett., 66, 1689 (1995)

[9] J.Z. Liu, I.C. Chang, S. Irons, P. Klavins, R.N. SheIton, K. Song, and S.R. Wassermann, Appl. Phys. Lett., 66, 3218 (1995)

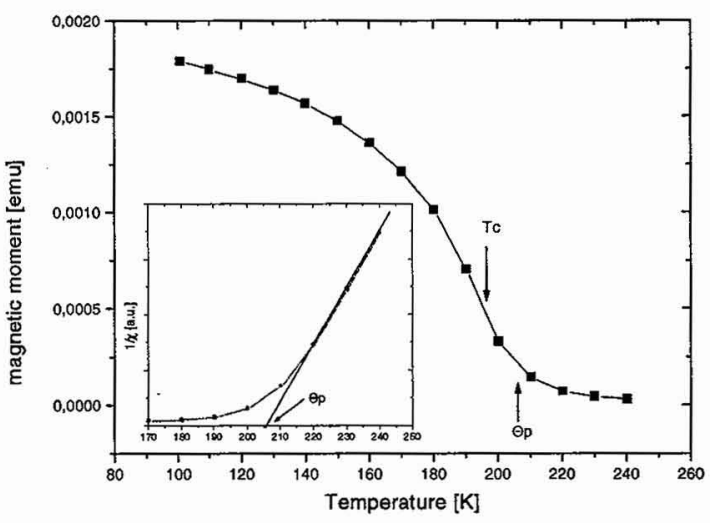

. The inset shows the linear extrapolation of the high-temperature susceptibility $1 / \chi$

Figure 2 : Magnetic field dependence of the resistance at $180 \mathrm{~K}$, $220 \mathrm{~K}$ and $300 \mathrm{~K}$ 